\title{
Estratégias para pensar (e reinventar) as relações entre corpo e poder
}

\author{
Christine Greiner
}

II

á pelo menos quatro décadas, pesquisas acerca do que é e de como age o poder têm sido relacionadas aos estudos do corpo. Autores como Michel Foucault, Gilles Deleuze e Giorgio Agamben vêm sendo citados insistentemente, apontando diferentes realidades políticas e suscitando interpretações distintas acerca de açôes de poder concernentes, por exemplo, à arte, ao direito e aos estudos da sexualidade.

Há referências mais antigas que constituíram, muitas vezes, as próprias fontes de discussão dos autores citados como os escritos de Antonin Artaud (no caso de Foucault e Deleuze), de Hannah Arendt (na releitura de Agamben) e dos pensamentos inaugurais de Nietzsche (sobre memória-esquecimento e o pensamento trágico) e Espinosa (sobre os afetos).

Nesse território, como em tantos outros, é arriscado apontar matrizes. Quem quiser pesquisar uma espécie de ontologia do poder descobrirá, ainda antes destes grandes nomes e suas respectivas obras, que já existiam investigações acerca das ações do poder e das representações e desestabilizações do corpo em tratados asiáticos e gregos, voltados aos estudos da medicina e das relaçōes entre corpo e ambiente. O campo me- dieval de estudos do corpo também traz contribuiçōes importantes reiterando a existência de diferentes modos de ver. Neste caso, o trânsito entre o ver e o não ver, evidencia-se no reconhecimento de que o corpo político mais sedutor da época, de fato, não estava mais lá. Para ser visto e lembrado necessitava de uma leitura simbólica. Michal Kobialka (ver 2003) explica que a chave para entender este "desaparecimento do corpo soberano" é "Hoc est corpus meum" ("Este é o meu corpo"), palavras de Cristo na última ceia repetidas, desde então, durante todas as celebraçôes da eucaristia. Ou seja, um corpo invisível que se fazia presente apenas através de ações metafóricas. Das representações do corpo ausente e soberano, vai se alimentar toda uma produção teatral e literária da época, investigando abordagens não apenas voltadas a um modelo estético dado, mas à discussão em torno da natureza desconhecida do corpo - nada estável, nem homogênea.

No século XVII, essa situação muda. Quem tem o poder não é mais o corpo de Cristo, mas o corpo do rei. Em Os dois corpos do rei, um estudo da teologia política medieval, Ernst Kantorowicz discute a potência absoluta e perpétua do rei que sobrevive à sua pessoa

Christine Greiner é professora do Departamento de Linguagens do Corpo da PUC-SP. 
física ("o rei não morre jamais"). A teologia política cristã destina-se - através da analogia com o corpo místico de Cristo - a assegurar a continuidade do corpo moral e político do Estado, sem o qual nenhuma organização política estável poderia ser pensada.

Nesta mesma época, não raramente, haverá uma correspondência entre partes e funções do corpo humano e partes e funções do corpo político, como uma estratégia metonímica. Leviatã (1651), de Thomas Hobbes, argumenta acerca da obediência à autoridade e discute o homem em seu estado natural. A concepção do corpo político é absolutamente antropomórfica.

Mas as regras continuam mudando. No entanto, a exclusão do jogo político, não raramente, continua atada a especificidades corporais. Escravos, estrangeiros, mulheres, crianças, colonizados, classes trabalhadoras, aparentemente são excluídos da participação política por motivos diversos, mas sobretudo pelo fato de serem considerados inapropriados à imagem de corpo político soberano. Um exemplo histórico clássico é o das amazonas, consideradas representantes de um corpo feminino político, que faziam mastectomia, mostrando que alguns aspectos metonímicos das metáforas do corpo pediam por uma exclusão. Não era mais a natureza tal e qual, mas uma corporeidade construída que poderia impedir ou definir a participação ativa na cena do poder.

A partir do século XIX, a imagem mística do corpo soberano mudou mais uma vez e passou a ser o corpo da sociedade que se transformou em um novo princípio. Assim como o corpo do monarca era sagrado, o da sociedade também precisava ser diferenciado. Ele não era mais místico no sentido cristão, mas asséptico. Para tanto, precisava ser preservado resultando no controle dos doentes, dos delinqüentes e na criação de muitos métodos de limpeza no sentido literal e ideológico da palavra como mostraram os estudos e experiências relacionadas à criminologia, à eugenia e diferentes táticas de exclusão.
Este corpo social parecia sempre assombrado pelo fantasma da universalidade das vontades, mas, curiosamente, não era o consenso que o gestava, e sim, a materialidade do poder que se exercia sobre o corpo dos indivíduos e parecia reforçar a homogeneidade, o padrão.

Nada é mais físico e material do que o exercício do poder, disse Michel Foucault em sua História da Sexualidade 1, a vontade de saber. Todos os regimes disciplinares nas escolas, hospitais, famílias, condomínios, são exercícios de poder. Mas não se deve imaginar que o poder é só repressão, impedimento. Foucault chama a atenção para o fato de como isso se dá, ou seja, não apenas de forma deflagrada e explícita, mas também camuflada. Isso porque o poder eficiente produz também efeitos positivos, agindo sobre o desejo e a produção de saber. Se não fosse isso ele não seria tão bem sucedido e duradouro. Atrás de toda ação de poder está a história política da produção de uma verdade. Para ser eficiente, mesmo que brutal, o poder e a produção da verdade precisam, de alguma maneira, ter alguma inserção no âmbito do desejo - não necessariamente do prazer, mas sempre do desejo.

Foucault avançou nesta investigação na medida em que não quis criar uma teoria do poder, mas fazer uma análise das ações do poder que tinham alguns traços principais, voltados para a discussão do sexo, mas facilmente identificados em muitas outras situações.

O primeiro traço, bastante evidente, é a relação negativa que seria, por exemplo, a rejeição, a exclusão, a recusa, a ocultação e o mascaramento. $\mathrm{O}$ poder nada pode contra o prazer a não ser dizer não. No que se refere aos tabus do sexo, tal rejeição é evidente, mas ela se evidencia também em muitas outras circunstâncias nas quais se o poder produz alguma coisa esta produção é identificada através de ausências e descontinuidades. $\mathrm{O}$ poder marca fronteiras.

O segundo traço, diz Foucault, é a instância da regra. O poder dita a lei e estabelece oposiçôes. Cria limites entre o lícito e o ilícito. Neste sentido é, normalmente, um ato de dis- 
curso. Ao criar leis, faz o que o próprio mecanismo do "fazer leis" propõe, ou seja, abstrai da realidade algo a ser estabilizado e que passa, a partir de então, a nortear comportamentos. A definição de uma lei física, por exemplo, reconhece sempre um ritmo e um padrão entre os fenômenos da natureza que não são, necessariamente, aparentes aos olhos. Existe ainda um outro nível de maior generalidade e que estaria ligado às próprias qualidades da natureza. Quando o poder dita uma lei ele opera em um nível aparente aos olhos. Não são nem as qualidades da natureza, nem os ritmos e padrões invisíveis, mas ritmos e padróes comportamentais de homens mergulhados em seus jogos de poder.

Outro traço que Foucault identifica é o chamado ciclo da interdição que sugere: não se aproxime, não toque, não consuma, não fale, não apareça. Este traço está relacionado à lógica da censura que afirma o que não é permitido e impede que se diga e negue que exista. Isto significa que o que é proibido não deve ser falado até que seja finalmente anulado no real. Inexistente é o que não tem lugar no discurso, não é sequer ser mencionado. A perda da voz marca, em grande parte, a ausência da ação. Walter Ong (1982) explica que a palavra falada é uma ocorrência, um evento evanescente, situacional, oracular, dialógico, agonístico e potente. A palavra escrita é diferente. É mais como uma coisa do que uma fala. É autônoma, irrespondível, fixada, desatada do autor, um vasto receptor de memória e uma fonte de abstração. A perda da voz refere-se a estas duas palavras: a falada e a escrita. A diferença é que são descontinuadas. De fato, açōes diferentes.

Um dos poderes mais absolutos que já se teve noticia foi o pátria potestas. Este reunia os três traços principais de poder: a relação negativa, a regra e o ciclo da interdição e, ainda por cima, concedia ao pai de família romano o poder de dispor da vida dos filhos e dos seus escravos. Neste caso, o poder estava intimamente relacionado à exposição, à morte e à alteridade. $\mathrm{O}$ que se encontra no começo das coisas não parece uma identidade inviolável das suas ori- gens, mas a discordância de outras coisas, a disparidade, o contato com outras superfícies, as capacidades de interação.

De alguma maneira, os estudos de Norbert Elias e Michel Foucault complementam-se ao estudar a civilização e a sociedade carcerária. Elias pensou na concentração da violência nas mãos do estado e Foucault, que também investigou como poucos o poder institucional (sanatório, clínica, prisão e escola) estendeu a discussão para as micropolíticas da vida cotidiana. A memória da lei que, de alguma forma, sistematiza estes dois níveis de violência cria representaçôes do corpo político tendo em vista regulamentar comportamentos, prescrevê-los, ou criar uma espécie de repositório de performances sociais. Quanto mais complexas são essas representações, torna-se mais claro que não existe só o corpo, mas o corpo em movimento que apresenta um ambiente de memória em ação que passa a especular em torno da mutação das tradições, criando um mapa de diásporas de pensamentos que não são apenas idas e vindas de pessoas, mas idas e vindas de uma rede de percepçōes, imagens e pensamentos.

Por isso, como tem discutido Boaventura de Souza Santos (ver 2006) não é mais possível insistir no estudo de certas questôes referentes às relaçooes de poder, partindo sempre das mesmas teorias e, pior ainda, da crença em teorias gerais, capazes de explicar e discutir relações de poder de maneira irrestrita.

Assim, por mais que as discussões apresentadas por todos os autores europeus tenham sido fundamentais para nossas pesquisas no Brasil, parece interessante deslocar por alguns momentos os eixos de análise. O projeto de Santos acerca da $A$ Reinvenção da Emancipação Social foi uma tentativa de estudar alternativas à globalização neoliberal e ao capitalismo global, observando o modo como movimentos sociais e organizações não governamentais têm operado na luta contra a exclusão e diversos tipos de discriminação. Ele escolheu seis países (Moçambique, África do Sul, Brasil, Colômbia, Índia e Portugal) onde identificou os conflitos mais 
significativos entre a globalização neoliberal e a globalização contra-hegemônica.

Além do estudo da democracia participativa, de sistemas de produção alternativa, de economia solidária, açôes multiculturalistas, direitos coletivos, pluralismo jurídico e exercícios de cidadania cultural, surgiram alternativas aos direitos de propriedade intelectual e proteção à diversidade epistêmica do mundo.

Neste sentido, diz Santos, é preciso observar também experiências que não estão necessariamente organizadas no Ocidente. Bons exemplos são os da filosofia africana proposta por Odera Oruka, que se chama "sageza filosófica”, ou seja, uma reflexão crítica protagonizada pelos sages, poetas, médicos tradicionais, contadores de histórias, músicos e autoridades tradicionais. Uma sabedoria que oscila entre a sabedoria popular e a sabedoria didática e reconhece que os pensamentos se expressam através da oralidade além da escrita, organizando-se através de provérbios, máximas e argumentos associados a certos indivíduos considerados sábios pelas suas respectivas comunidades. Outro exemplo é o do sociólogo indiano Vishvanathan que diz que o seu maior problema é o de como relacionar o melhor que a civilização indiana possui e, ao mesmo tempo, manter viva a imaginação moderna e democrática.

Dentro da reflexão proposta por Santos, é providencial lembrar as ações do japonês Murakami Takashi, sobretudo no que se refere às políticas culturais. Murakami nasceu em 1969 e, nos últimos anos, tem refletido, como poucos, acerca da obsessão pela cultura consumista. Ele não tem vergonha de ser o que os japoneses chamam de otaku ("nerds"). Ao contrário, ele sente orgulho de fazer parte desta geração, produzindo pinturas, esculturas e cartoons inspirado por merchandising e cultivando o que chama de $p o k u$, que seria a mistura entre pop e otaku.

Um dos ícones que criou foi My Lonesome Cowboy, um boneco caracterizado como superherói de mangá, que se apresenta nu, ejaculando um líquido branco com exuberância. Murakami está apresentando a masturbação como uma das atividades mais reincidentes dos otakus. A versão feminina de Lonesome é uma boneca com cara de menina, também de plástico, que não tem genitália, embora esteja semi-nua. De seus seios enormes sai um líquido branco que faz referência ao leite materno. O seu nome é Hiropon, uma metanfetamina popular durante o período do pós-guerra no Japão.

Em 1999, Murakami foi objeto de uma grande exposição em Nova York, chamada The Meaning of the non sense of the meaning. Ele mesmo escolheu o título para glorificar a sua deliberada e aparente inconseqüência. Para Murakami Trash is cool, trata-se de viver o absolutamente comercial e derivativo. Os seus objetos trabalham a estética pop e kitsch do Japão, sem observar com tanta curiosidade as experiências estadunidenses, embora a referência a artistas como Jeff Koons seja evidente, inclusive na criação dos bonecos e bonecas sensuais. Mas o ponto mais interessante da discussão proposta por Murakami está relacionado ao fato de que ele faz parte de uma geração cuja infância foi toda mergulhada na prosperidade do consumo e na influência da mídia, do mangá e do animê. O new pop ou $j$-pop instanciou uma subjetividade poética que de forma, mais ou menos explícitas, passou a refletir sobre esta condição social. Muitos integrantes atuantes deste circuito não são apenas artistas, mas produtores como o próprio Murakami que é fundador da Hiropon Factory, agora chamada de Kaikai Kiki Co. Ltda. Além de chamar outros jovens artistas para apresentar suas obras, ele quer propiciar também condições de trabalho para alguns deles, alimentando a produção artística que se estende bem além dos limites do museu e da galeria. Além da internet, eles produzem camisetas, livros e todo tipo de produto que se relaciona ao universo mangá. Quando começou, em 1989, Murakami não tinha dinheiro para nada. Mesmo assim, chamou meia dúzia de estudantes e amigos que decidiram trabalhar recebendo apenas um lanche como ajuda de custo. Em cinco anos haviam quarenta pessoas 
envolvidas nos projetos. Um exemplo interessante é o de Takano Aya que, em 1996, aos vinte anos, começou a trabalhar na Hiropon Factory e no ano seguinte, quando fez a sua primeira exibição em Tóquio, teve $90 \%$ dos seus trabalhos vendidos imediatamente. O que interessava a todos era abrir caminhos para a cena artística internacional. Aparecer em algumas das exposições e eventos. Fazer contatos. Quando muda o nome da Hiropon Factory para Kaikai Kiki (termo que tem a ver com supernatural e bizarre), Murakami muda o foco da sua pesquisa e seus modos de produção. Ao invés de continuar pensando coletivamente a arte pop, os participantes passam a criar cada vez mais produtos e estes passam a ter vida própria. São os produtos que passam a apresentar um pensamento.

Sem pensar que o que se é constitui a somatória de acontecimentos (e pessoas), ainda assim há episódios que marcam certo modo de ver e sentir as coisas. Em seu manifesto Super flat de 2000, ele diz que super flatness é um conceito original do japonês que tem sido completamente ocidentalizado. A inspiração é flagrante no $p o p$ americano do final dos anos 1950 e começo dos 1960. Jasper Johns, Robert Rauschenberg, Andy Warhol e Roy Lichenstein já se valiam de muitos artifícios reutilizados pelos japoneses. O uso de objetos cotidianos, a transformação de símbolos da nação em bens de mau gosto, consumíveis. Mas a arte no Japão tem suas especificidades. O próprio Murakami diz que há uma diferença radical em relação ao Ocidente e que ela reside no fato da arte e da estética no Japão terem sido muitas vezes uma espécie de auto-esquecimento que a tornaram parte do mundo cotidiano ou de um certo estilo de vida. Isso porque a arte no Japão sempre foi a expressão de uma coletividade e não de um princípio de individualidade ou a ação de um sujeito.

Os debates de Murakami e tantos outros fóruns de discussão organizados pelo mundo na última década, demonstram que o consumo, a produção e os processos de violência que permeiam, de maneira implícita ou explícita, boa parte das ações no mundo, identificam perdas significativas. Melhor dizendo, a violência que nasce do exercício de poder é, inevitavelmente, a performance da perda. Ela é performativa porque sempre precisa de público, nem que seja apenas a própria vítima ou Deus. Ela é também sempre excessiva. Para demonstrar-se, ela gasta coisas, objetos materiais, sangue, pessoas. São os atos de um gasto improdutivo como George Bataille (ver 1967) costumava discutir. Trata-se de uma genealogia de pensamentos que investigam a relação entre o poder, o corpo, a perda e a exposição à morte.

Um dos primeiros autores a tratar desta questão foi Marcel Mauss que falava no dom, nas formas e nas funções da troca nas sociedades arcaicas (1924). Aspectos da sua discussão foram repensados por Bataille, depois por Jacques Derrida (1991) e Arjun Appadurai (1986). Todos estes autores pretendiam discutir uma economia de abundância que não é necessariamente abundância de dinheiro, mas de todo tipo de excesso (fetiche, dor, angústia, prazer, consumo, sexo e assim por diante). Tanto em Mauss como em Bataille e nos outros autores mencionados, há uma relação entre abundância, reprodução e sacrifício - a vítima sacrificada, destinada ao consumo violento. Bataille mostrou como rituais e sacrifícios não são exclusividades dos povos bárbaros. Como dizia Walter Benjamin, não há documento da civilização que não tenha sido, ao mesmo tempo, um documento de barbárie.

A obra de Murakami redimensiona algumas destas questões. Evidencia a inevitabilidade de alguns processos sem camuflar o que vem sendo deixado para trás. Não é um modelo a seguir, mas uma referência que ao deslocar princípios e pré-conceitos satiriza estereótipos de todo tipo e, por isso mesmo, merece a nossa atenção. 


\section{Referências bibliográficas}

APPADURAI, Arjun. The social life of things: commodities in cultural perspective. Cambridge University Press, 1986.

AGAMBEN, Giorgio. Homo Sacer, o poder soberano e a vida nua 1. Trad. de Henrique Burigo, Col. Humanitas, Ed. UFMG, 2004.

BATAILLE, Georges. Oeuvres Completes vol 1 e 2. Paris: Gallimard, 1967.

DELEUZE, Gilles et GUATTARI, Felix. Capitalisme et schizophrénie 2 Mille Plateaux. Lês Éditions de Minuit,1980.

DERRIDA, Jacques. Donner le Temps. Paris: Galilée, 1991.

ONG, Walter J. Orality and Literacy: The Technologizing of the Word. Routledge, 1982.

FOUCAULT, Michel. História da Sexualidade 1, a vontade de saber. Graal, 17 ed, trad. Maria Thereza da Costa Albuquerque e J.A. Guilhon Albuquerque, 2006.

GREINER, Christine. O Corpo: pistas para estudos indisciplinares. Annablume, 2005.

KOBIALKA, Michal. This is my body. Minnesota University Press, 2003.

MURAKAMI, Takashi (ed). Little Boy The Arts of Japan's Exploding Subculture. Japan Society and Yale University Press, 2005.

SANTOS, Boaventura de Souza. Gramática do Tempo. Cortez, 2006. 